\title{
The Impact of Gender on the Foreign Language Anxiety of the Yemeni University Students
}

\author{
Dr. Nemah Abdullah Ayash Ezzi \\ Assistant Professor (ELT: TEFL,TESL) \\ Department of English, Faculty of Education \\ University of Hodeidah, Republic of Yemen
}

Tel: +967-712451220. E-mail: nemahayash2000@yahoo.com

Received: 13-05- 2012

Accepted: 13-06- 2012

Published: 01-07- 2012

doi:10.7575/ijalel.v.1n.2p.65

URL: http://dx.doi.org/10.7575/ijalel.v.1n.2p.65

\begin{abstract}
University students have to communicate using FL in the classrooms. This demand makes students anxious and leads to FL anxiety. This study aims to measure the levels of FL anxiety perceived by the Yemeni students of the English Department in the Faculty of Education at Hodeidah University. It also investigates the relationship between FL anxiety and gender among male and female students with regard to their educational level, age and residence. An Arabic, adapted, piloted and revised version of the FLCA scale (Horwitz, Horwitz and Cope 1986) is used. It is found that students (males and females) have a high level of FL anxiety but female-students' anxiety is higher than male-students'. Like gender, age and residence factors strongly contribute to FL anxiety. However, there is no significant difference of the levels of anxiety between the two levels. Ultimately, the study brings about pedagogically based suggestions to alleviate students' FL anxiety.
\end{abstract}

Keywords: Foreign language classroom anxiety (FLCA), university students, scale, gender

\section{Introduction}

Language anxiety is experienced by all students of SL and FL (Campbell \& Ortiz 1991) but it is very high in FL learning (Siegel 1989). Campbell \& Ortiz (1991) estimate that up to half of all language students, experience levels of language anxiety. Horwitz et al. (1991) indicate that anxiety was significantly related to poor performance in the FL, particularly in speaking skills. Language anxiety can be defined as "the apprehension experienced when a situation requires the use of a SL with which the individual is not fully proficient, this apprehension being characterized by 'derogatory self-related cognitions... feeling of apprehension and physiological responses such as increased heart rate” (MacIntyre \& Gardner 1993:5). It is "linked directly to performing in the target language, so it is not a general performance anxiety" (MacIntyre \& Gardner 1993, Horwitz, \& Cope 1986, as in Arnold 1991). Some researchers believe that the kind of anxiety, which affects FL learners, is of a special kind that is called by Horwitz et al. (1991) as Foreign Language Anxiety and defined as "feeling of tension, apprehension and nervousness associated with the situation of learning a Foreign Language". FL Anxiety is a state or situational and not trait-anxiety because it is not stable but transitory and fluctuated over time and situation "apprehension experienced at a particular moment in time", for example, having to speak in a FL in front of classmates (Spielberger, 1983). Foreign language classroom anxiety (FLCA) has been extensively researched since Horwitz et al. (1986). Horwitz, Horwitz and Cope (1986) believed that foreign language classroom anxiety was responsible for students' negative emotional reactions to language learning since they had to deal with a totally foreign language and culture.

\subsection{English as a Foreign Language in Yemen}

English is a foreign language in Yemen. It is taught from the seventh grade of the primary school as a compulsory subject. Students of different levels use English only inside the classrooms. Some of them use it outside the classrooms or colleges for restricted purposes e.g. giving direction to a tourist. University students may need to use English more than those in the lower levels to understand and be understood by the non-Arabic speaking teachers as long as they study in different universities. Later, they need to speak English to deal with their colleagues in offices, banks, factories or wherever they work with non-Arabic speakers.

Page $\mid 65$ 
International Journal of Applied Linguistics \& English Literature

ISSN 2200-3592 (Print), ISSN 2200-3452 (Online)

Vol. 1 No. 2; July 2012

Like other developing countries, Yemen has had a sustained move to build a 'language-competent society' including competence in English, the international language of today. Further, more and more Yemeni people realized that they need more English everyday and in the days to come to achieve everyday tasks (Ezzi, 2006).

All this make it a load on the university students who need a kind of 'bread-better' English for survival so they have to learn how to speak it well. This demand leads students to the problem of FL anxiety.

\subsection{Teaching English at the Yemeni Universities: A Gender Gap}

Gender is a significant variable in language learning process. It has important theoretical and pedagogical implications in L2 and FL learning. In the Yemeni context, it plays a great role in teaching English as a foreign language to the male and female students in the English departments, colleges/faculties at Yemeni universities.

The Yemeni school system has two levels namely, primary (nine years) and secondary (three years). At these levels, there are schools for boys and schools for girls i.e. students are separated at all educational levels except at the college level where they are mixed. But the mixed classes in the universities are not really mixed as some people think. In each classroom, girls' seats are separated from boys' seats and located inside the classrooms by the left side windows while boys' seats are located inside the classrooms by the doors. So there are Two Big Groups segregated from each other inside each classroom, in the English Departments and all the different disciplines. This seating arrangement is a replica of the real world situation and originated from the religious and social beliefs of the Yemeni society that "women don't socialize with men other than the family members" and socially "women are inferiors than men so they are given lower status than men" (Ezzi, 2003). The Islamic beliefs should not be separated from the life of Muslims but they must be respected and applied in all the different contexts including the classroom i.e. a small environment, as they are miniature community which is formally structured to imbibe all aspects of the life of the community (Mukalel, 1998).

Most of the college students are girls. For example, at Hodeidah University, Faculty of Education, the proportion of the sexes undergoing B.Ed courses in English is as follows: three girls to one boy. Administrators in the Faculty expect the proportion of girls to boys to increase sharply in the coming years. So girls constitute the majority of English students inside the classrooms. This is true in all the other disciplines, not only in English. In addition, the proportion of women teachers among the faculty teaching-staff is smoothly increasing. Some years back, you could hardly find women teachers in the different departments. But nowadays you can find a set of women in each department. I am, for example, one of the members in the English Department there (Ezzi, 2003).

\section{Background}

Traditional ELT methods, e.g. Grammar-Translation, do not give a space for learners as individuals with different personalities, needs and problems. Teacher is the authority that always does everything in the class, initiates drills, directs interaction, i.e. one - way interaction (teacher $\rightarrow$ students interaction), and controls the classrooms. In other words, learners' affective/internal factors are neglected since learners have to practice mechanically a bundle of structures and drills and have no chance to express themselves in the target language. However, the advent of methods, which focus on communication in the target language, e.g. Communicative Approaches, learners' personal aspects and feelings, are taken into consideration. Bernat (2002) points out that rejecting the cognitive-centeredness of previous language learning research, foreign and second language educators are currently beginning to recognize the importance of the learner's role in the both the cognitive and affective domain in the language learning process. Consequently, there has been a greater understanding and appreciation of affective variables as the way learners feel about themselves and their capabilities has either negative or positive effect on language learning.

Anxiety is one of the affective factors that can greatly hamper learners' language performance because of its negative effects. It can plummet learners' motivation, create negative attitudes and inhibits communication in the classroom. The importance of language anxiety has led to significant research and discussion on its causes and effects on language learning e.g. (Aida, 1994; Bailey, 1983; Horwitz, Horwitz, \& Cope, 1986; Horwitz \& Young, 1991; MacIntyre \& Gardner, 1993 and Von Wörde 1989).

However, Horwitz, Horwitz and Cope (1986) were the first researchers who developed a complete research instrument specifically focused on the learner's experience of anxiety inside the foreign language classroom. After forming a support group for students who were having difficulties in learning languages and on the basis of students 'reported experiences, Horwitz et al. (1986) devised a Likert scale of five points which consisted of 33 items and was aimed at probing students' experiences of anxiety related to the learning of a foreign language in the classroom context, i.e. Foreign Language Classroom Anxiety Scale or the (FLCAS). According to Horwitz et al. (1986), there are three main interrelated factors that intervene in the foreign language

Page $\mid 66$ 
International Journal of Applied Linguistics \& English Literature

ISSN 2200-3592 (Print), ISSN 2200-3452 (Online)

Vol. 1 No. 2; July 2012

classroom anxiety experience: communication apprehension or fear about real or anticipated communication with other people, test anxiety or fear of failing in test situations and fear of negative evaluation.

MacIntyre (1999) maintains that anxiety can affect emotions, cognition and behavior. An interaction is often found among anxiety, task difficulty and ability, which interferes at the input, processing, retrieval and at the output level. If anxiety impairs cognitive function, students who are anxious may learn less and may not be able to demonstrate what they have learned. Horwitz (Horwitz et al. 1986) have found that language anxiety can cause students to postpone language study indefinitely or to change majors. Gregerson (2003) suggests that anxious learners suffer from mental blocks during spontaneous speaking activities, lack confidence, are less able to self-edit, identify language errors and are more likely to employ avoidance strategies such as skipping class. Liu (2008) indicates that the effects of language anxiety also extend outside the second language classroom, causing individuals to be quieter and less willing to communicate.

The prevalence of FL anxiety inspired researchers to study it with regard to different variables such as gender, age, educational level and place of residence. Studies of Padilla, Cervantes, Maldonado \& García 1988; Plancherel \& Bolognini 1995; Gierl \& Rogers 1996; Chang, 1997; Wei \&Yodkamlue 2012, have focused on FL anxiety and gender and shown that female learners are more concerned about language complications compared to male ones and that they are more anxious and worry-oriented than male students. A recent research of Jafarigohar \& Behrooznia (2012) investigates the relationship between FL anxiety and age. It is found out that age doesn't have any significant effect on foreign language anxiety in distance education, and the observed differences were probably due to chance alone.Wei \& Yodkamlue's research (2012) explores whether there is a relationship between FL anxiety and educational level of the subjects. It indicates that first-year students reported experiencing overall FL classroom anxiety more frequently than second-year students, whereas Puškar (2010) finds out that neither first-year English or German students nor second/third-year students experienced higher levels of FL anxiety. Yet, significant research of Piechurska-Kuciel (2012) and Puškar (2010), which is on FL anxiety with regard to the place of residence, indicates that students from villages (rural areas) tended to experience higher language anxiety levels than students from the city (urban areas).

\section{Problem of the study}

We live in an educational world where orality is seen as a necessary, positive personal characteristic (Daly, 1991 cited in Tanveer, 2007:5).The importance of English language in Yemen as a developed country, for butter-bread purposes, has increased the demand to speak English well and acquire good communication skills. However, the interactive nature of the language in the classrooms and the continual requests on students to communicate in the target language are likely to make language classrooms more anxiety-inducing than other classroom contexts. Ezzi (2012) suggests that students' inadequate vocabulary, insufficient grammatical knowledge of the target language, inability to comprehend, fear of negative evaluation either by the teacher or the classmates and teachers' immediate correction of errors contribute to language anxiety in FL classrooms. FL anxiety is an obvious problem as students of different levels often express their feeling of uneasiness, stress, worry or anxiety which obstructs learning process, "even in optimum conditions, students can experience destructive forms of anxiety" (Reid 1999).

This problem exists among both beginners and advanced language students who feel anxious in the English classes particularly while speaking English within classrooms. Advanced students complain from language anxiety and wonder why they can't speak English well and their great efforts don't lead to the intended performance. Language anxiety harms students' performance indirectly through fear and worry and directly by reducing participation in the classroom and overt avoidance of the language classes. The researcher, as a teacher-trainer with much teaching experience, observes this phenomenon among university students of English of different levels.

\section{Purpose of the Study}

This study mainly aims to measure the level of FL anxiety of university students. It investigates the relationship between foreign language classroom anxiety and gender among male and female Yemeni students in the Department of English at the Faculty of Education-Hodeidah University with regard to the factors of educational levels, age and residence. It seeks answers to the following questions:

1. How is the level of FL anxiety of the students in the English Department?

2. Are the gender differences contribute to FLCA of the selected university students in the English Department?

3. Who have higher level of FLCA: male or female students?

Page 67 
International Journal of Applied Linguistics \& English Literature

ISSN 2200-3592 (Print), ISSN 2200-3452 (Online)

Vol. 1 No. 2; July 2012

4. Are second-year English students more anxious about using English than fourth-year students?

5. Are students who reside in Hodeidah more anxious than those who live outside Hodeidah?

\section{Research Design}

\subsection{Participants}

The subjects are 163 students: 84 (i.e. 6 males and 78 females) are second-year students and 79 (i.e. 6 males and 73 females) fourth-year students. The total number of the male-students of both levels is 12 while the females are 151. They are undergoing B.Ed four-year course in the Department of English at the Faculty of Education affiliated to Hodeidah University. Though female-students outnumber male- students, Mann-Whitney test helps to compare between the two groups of unequal size.

Table 1. Showing gender-wise statistics of the subjects of the study

\begin{tabular}{cccc}
\hline Levels & Female & Male & Total \\
\hline Second-year & 78 & 6 & 84 \\
Fourth-year & 73 & 6 & 79 \\
Total & 151 & 12 & 163
\end{tabular}

\subsection{Instruments}

The research instrument used for this study is a translated version of the FLCAS designed by Horwitz et al. (1986). Originally, the scale is of five points (agree, strongly agree, neutral, disagree, strongly disagree) and consists of 33 items. It has been translated then adapted. Four items are added at the end of it, following the same way of response to serve the purpose of the study. The scale is preceded by an introductory demographical details of students (e.g. gender, age, level, place of residence) which serve the purpose of this study .

Several reasons has encouraged the researcher to use FLCAS in her study. On the one hand, this scale has been designed on the basis of previous in-depth qualitative research, which renders it as one of the most comprehensive and valid instruments that are available for measuring the situational anxiety directly associated to the specific context of the foreign language classroom. On the other hand, the scale has demonstrated satisfactory reliability coefficients with the first samples of population to which it has administered (Horwitz 1991). In fact, it is the most frequently scale used nowadays, often shortened or adapted in other studies concerned with similar purposes.

The subjects have been provided with clear, explicit and unambiguous instructions given in Arabic. It is translated into Arabic though it is given to English students because the researcher wants the Arabic version of the scale to be as faithful as possible to the original English scale and to get reliable results. Also, students' level of English is unsatisfactory that they may find it difficult to understand all the items in English. The Arabic version is subject to critical scrutiny in the pilot phase of the study and has tried by a group of 20 university students of English (e.g. third-year students). The same group responded to the questionnaire twice (on two Saturdays) respectively as Saturday marks the beginning of the week and almost all the levels of the students have classes. Results are compared and correlated with the initial questionnaire to measure stability. Also, Students' responses are analyzed to measure validity and finds out whether the items within the questionnaire agree with each other (viz. internal validity), i.e. do the subjects respond to the similar items in the questionnaire in similar ways? This process helps in testing the clarity of questionnaire's translated items and revised them accordingly.

\subsection{Data Collection}

Then questionnaires are administered and collected by the researcher herself during the class-times. She has got the participants' responses to the questionnaire's items at their classes with the help of their teachers. Responding to the questionnaire lasted 5-10 minutes of the class time.

\subsection{Data Analysis}

The data are analyzed using Statistical Package for Social Sciences (SPSS/version 17). Arthematic mean, standard deviation and t-test are used in this study to compare between different data of gender-wise groups of two different levels. Mann-Whitney test is also used to compare between two groups of unequal size (one of them is large and the other is small as the participants of this study, see table no.1). The level of significant is 0.05 .

Page $\mid 68$ 


\section{International Journal of Applied Linguistics \& English Literature}

ISSN 2200-3592 (Print), ISSN 2200-3452 (Online)

Vol. 1 No. 2; July 2012

\section{Results}

Table 2 reveals that all statements are significant except statements no. 2, 5, 6, 8, 28, 34. See the Appendix.

Table 2 . Showing the validity and stability of the translated then adapted questionnaire

\begin{tabular}{|c|c|c|c|c|c|c|}
\hline $\begin{array}{l}\text { No. of } \\
\text { items }\end{array}$ & $\begin{array}{l}\text { Correlation } \\
\text { coefficient }\end{array}$ & $\mathrm{P}$ & Validity & $\begin{array}{c}\text { Power of } \\
\text { items }\end{array}$ & Probability & Specificity \\
\hline 1 & .433 & .001 & Valid & 3.901 & .001 & Specific \\
\hline 2 & .207 & .01 & Valid & 1.151 & Not significant & Non specific \\
\hline 3 & .590 & .001 & Valid & 6.521 & .001 & Specific \\
\hline 4 & .335 & .001 & Valid & 3.890 & .001 & Specific \\
\hline 5 & .173 & .05 & Valid & 1.109 & Not significant & Non specific \\
\hline 6 & -.197 & .05 & Non valid & $-1.735-$ & Not significant & Non specific \\
\hline 7 & .603 & .001 & Valid & 6.785 & .001 & Specific \\
\hline 8 & .009 & Not significant & Non valid & $-.559-$ & Not significant & Non specific \\
\hline 9 & .526 & .001 & Valid & 6.311 & .001 & Specific \\
\hline 10 & .573 & .001 & Valid & 7.047 & .001 & Specific \\
\hline 11 & .176 & .05 & Valid & 1.186 & .239 & Specific \\
\hline 12 & .335 & .001 & Valid & 4.756 & .001 & Specific \\
\hline 13 & .522 & .001 & Valid & 7.860 & .001 & Specific \\
\hline 14 & .267 & .001 & Valid & 3.018 & .01 & Specific \\
\hline 15 & .193 & .05 & Valid & 2.466 & .01 & Specific \\
\hline 16 & .477 & .001 & Valid & 6.058 & .001 & Specific \\
\hline 17 & .269 & .001 & Valid & 2.602 & .01 & Specific \\
\hline 18 & .264 & .001 & Valid & 2.738 & .01 & Specific \\
\hline 19 & .457 & .001 & Valid & 5.218 & .001 & Specific \\
\hline 20 & .682 & .001 & Valid & 8.803 & .001 & Specific \\
\hline 21 & .284 & .001 & Valid & 3.629 & .001 & Specific \\
\hline 22 & .219 & .01 & Valid & 2.436 & .01 & Specific \\
\hline 23 & .639 & .001 & Valid & 7.400 & .001 & Specific \\
\hline 24 & .745 & .001 & Valid & 11.643 & .001 & Specific \\
\hline 25 & .477 & .001 & Valid & 6.153 & .001 & Specific \\
\hline 26 & .511 & .001 & Valid & 6.115 & .001 & Specific \\
\hline 27 & .589 & .001 & Valid & 8.096 & .001 & Specific \\
\hline 28 & .055 & Not significant & Non valid & -1.875 & .064 & Non specific \\
\hline 29 & .493 & .001 & Valid & 5.553 & .001 & Specific \\
\hline 30 & .408 & .001 & Valid & 4.786 & .001 & Specific \\
\hline 31 & .623 & .001 & Valid & 9.810 & .001 & Specific \\
\hline 32 & .298 & .001 & Valid & 2.803 & .001 & Specific \\
\hline 33 & .487 & .001 & Valid & 4.411 & .001 & Specific \\
\hline 34 & .244 & .01 & Valid & 1.459 & .148 & Non specific \\
\hline 35 & .240 & .01 & Valid & 2.279 & .05 & Specific \\
\hline 36 & .177 & .05 & Valid & 2.184 & .05 & Specific \\
\hline 37 & .271 & .001 & Valid & 3.491 & .001 & Specific \\
\hline
\end{tabular}

Page $\mid 69$ 


\section{International Journal of Applied Linguistics \& English Literature}

ISSN 2200-3592 (Print), ISSN 2200-3452 (Online)

Vol. 1 No. 2; July 2012

Table 3 Displays the statistics regarding the level of students' FL anxiety.

Table 3. Level of students' FL anxiety

\begin{tabular}{ccccccc}
\hline $\begin{array}{c}\text { Sig. } \\
\text { (2-tailed) }\end{array}$ & $\mathrm{T}$ & $\begin{array}{c}\text { Mean } \\
\text { Difference }\end{array}$ & $\begin{array}{c}\text { Std. Error } \\
\text { Mean }\end{array}$ & $\begin{array}{c}\text { Std. } \\
\text { Deviation }\end{array}$ & Mean & $\mathrm{N}$ \\
\hline 0.05 & 1.974 & 2.497 & 1.265 & 16.148 & 95.50 & 163 \\
\hline
\end{tabular}

The table above gives an idea about the general level of the students' FL anxiety. It clearly seems that the level of the students' anxiety is high as the mean anxiety is 95.50. Thus, students suffer from FL anxiety and teachers should pay attention to such a problem.

Table 4 shows the gender-wise statistics regarding the relationship between the students' gender and the level of FL anxiety.

Table 4. Relationship between the students' gender and the level of FL anxiety

\begin{tabular}{cccc}
\hline Anxiety & Male & Female & Total \\
\hline Mean & 89.33 & 95.40 & 95.50 \\
S.D. & 10.845 & 15.69 & 16.148 \\
S. error mean & 1.436 & 2.07 & 1.265 \\
U-test & & 2.366 & \\
p & & $0.05^{*}$ & \\
\hline
\end{tabular}

It is clear from the table that there is a significant increase in anxiety in the female-students than in the malestudents. The mean anxiety of the male-students is $89.33 \pm 10.845$, while it is $95.40 \pm 15.69$ of the female-students, the $\mathrm{p}$ value was $(0.05)$.

Table 5 presents the statistics regarding the relationship between the levels of the students and the level of anxiety.

Table 5. Relationship between the levels of the students and the level of anxiety

\begin{tabular}{cccc}
\hline Anxiety & Level 2 & Level 4 & Total \\
\hline Mean & 96.33 & 94.65 & 95.50 \\
S.D. & 17.42 & 15.47 & 16.148 \\
S. Error Mean & 2.16 & 1.91 & 1.265 \\
$\mathrm{~T}$ & & & \\
$\mathrm{p}$ & & 0.564 & \\
\hline
\end{tabular}

The table above reveals the difference between the two levels of the students (the second and the fourth levels) regarding the level of FL anxiety. It is found that the level of anxiety of second-year students is $96.33 \pm 17.42$, while the level of fourth-year students' anxiety is $94.65 \pm 15.47$. Comparing the two levels, it is found that there is no significant difference between the two levels regarding the anxiety score $(\mathrm{p}>0.05)$.

Table 6 shows the statistics regarding the relationship between the residence of the students and the level of anxiety.

Table 6. Relationship between the residence of the students and the level of anxiety

\begin{tabular}{cccc}
\hline Anxiety & In Hodeidah & Out of Hodeidah & Total \\
\hline Mean & 85.41 & 71.27 & 95.50 \\
S.D. & 32.42 & 46.04 & 16.148 \\
S. error mean & 3.87 & 5.50 & 1.265 \\
T & & 2.71 & \\
p & & $0.01 *$ & \\
\hline
\end{tabular}

Page $\mid 70$ 
International Journal of Applied Linguistics \& English Literature

ISSN 2200-3592 (Print), ISSN 2200-3452 (Online)

Vol. 1 No. 2; July 2012

It is found that the level of anxiety of the students who reside in Hodeidah is $85.41 \pm 32.42$, while the anxiety of those students from places outside Hodeidah is $71.27 \pm 46.04$. Here, there is a significant increase in anxiety level of students residing in Hodeidah than those who are living outside Hodeidah.

Table 7 displays the statistics regarding the relationship between the age of the students and the level of anxiety.

Table 7. Relationship between the age of the students and the level of anxiety

\begin{tabular}{cccc}
\hline Anxiety & Less than 25 years & More than 25 years & Total \\
\hline Mean & 94.79 & 96.84 & 95.50 \\
S.D. & 17.56 & 13.07 & 16.148 \\
S. error mean & 1.69 & 1.74 & 1.265 \\
T & & 0.767 & \\
p & & 0.388 & \\
\hline
\end{tabular}

The subjects of the study are either less than 25 years old or more than 25 years. The mean anxiety of those who are less than 25 years is $94.79 \pm 17.56$, while it is $96.84 \pm 13.07$ of those who are more than 25 years old. Through comparing the two age groups, it is found that there is no significant difference between them regarding the anxiety level. $(\mathrm{p}>0.05)$.

\section{Discussion}

Consistent with the findings of previous research (e.g Horwitz \& Young, 1991), this study indicates that the level of FL anxiety of English students, undergoing B.Ed four-year course in the Faculty of Education at Hodeidah University, is so high as the mean anxiety is 95.50. Like the findings of some research (e.g. Gierl \& Rogers 1996 ; Chang 1997), it is found that FL anxiety of female students is higher than it is in males. Thus, gender differences strongly contribute to the increase of the level of FL anxiety among Yemeni university students of English departments.

Unlike some research (e.g. Wei \& Yodkamlue, 2012), which finds out that freshmen have higher level of FL anxiety than the sophomores, this study finds out that there is no significant difference between the two educational levels of the students in this study regarding the FL anxiety score. Also, it diverges from other studies (e.g. Jafarigohar \& Behrooznia, 2012) as it finds out that students older in age experience a higher level of anxiety than younger ones.

Although this present study is congruent with some studies (e.g. Piechurska-Kuciel, 2012 and Puškar,2010) in the finding that there is a significant difference between the level of FL anxiety of students, who reside in the city and of those who reside outside the city, it doesn't match with them in the sense that students who reside in the city (viz. Hodeidah) suffer from a higher level of anxiety than those who reside outside the city.

\section{Conclusion}

Our translated - piloted and revised - version of the FLCAS has intended to offer a suitable research instrument that can be used in the Yemeni context not only with the students of English at university but also with students of any other foreign language. According to the results of the study, crossing off items no. 2, 5, 6, 8, 28,34 of the questionnaire makes the questionnaire a specific and valid instrument that can be actually used either by researchers interested in the topic of language anxiety or by the teachers to measure the level of FL anxiety of the Yemeni university students, undergoing English courses.

Here, it is revealed that FL anxiety levels among university students of the English Department are so high. This is worth considering and needs continuous research on the phenomenon of language anxiety for two reasons: on the one hand, the use of communicative methodologies implies greater demands on students to communicate using English and therefore they are highly exposed to anxiety-inducing situations; on the other hand, the number of students of English departments at the Yemeni universities is so large and in increase, comparing it with the number of students of other departments.

Gender has its impact on FL anxiety of the university students as the level of anxiety among female-students is higher than the anxiety among males, the mean anxiety is $95.40 \pm 15.69$. So, it does make a difference whether the student, who speaks English in the classroom and in front of classmates, is a female or male, at the Yemeni context. Teachers should keep this into consideration while teaching English.

Page $\mid 71$ 
International Journal of Applied Linguistics \& English Literature

ISSN 2200-3592 (Print), ISSN 2200-3452 (Online)

Vol. 1 No. 2; July 2012

The educational level of students has no effect on the level of their language anxiety as there is no significant difference between the two levels of the students in this study regarding the anxiety score $(\mathrm{p}>0.05)$. However, the factors of age and residence contribute to FL anxiety and increase the level of students' anxiety. Students who are older in age (i.e. more than 25 years) have a high level of anxiety like those students who reside inside Hodeidah city.

\section{Recommendations}

Based on the findings reached, the study presents some recommendations and pedagogically based suggestions that would presumably be applicable to the whole population of the university students of the English departments in the faculties of education. For alleviating/reducing students' FL anxiety, a relaxed, anxiety-free and supportive atmosphere is necessary for the students to make use of whatever opportunities may be available to them. A teacher may try these suggestions to create such an atmosphere:

Teachers should encourage their students through employing non-threatening teaching methods and use appealing. They may deal with students informally, as friends. They should make a short talk on anxiety, from the outset of the classes, to make students aware of that anxiety is a common problem for all students of all levels and they are not alone suffering from anxiety. Students should know the negative effects of it to enable them overcome it.

Voices of students should be heard and appreciated by teachers for valuable insights, ideas and suggestions. Students should feel that it is their own right to say 'I think' and 'I don't think' inside the classroom. All teachers should be sensitive to students' fear and insecurities and help them to confront those fears. Accordingly, they should talk slowly while presenting the new language and make everything clear for students.

Students shouldn't be conscious of their language errors all the time because they will not be able to express their ideas in real communicative situations. Also, the emphasis in language classroom on correct use of language forms leads to what Dakin (1973) refers to as a strange language-like performance or 'structure speech', which is correct drill performance but not real communication. Teachers, therefore, should neither insist on 'error-free' communication nor ignore all the students' errors. But they may interfere and correct the errors gently if their communication gets totally spoiled i.e. it becomes meaningless.

Selecting suitable topics that motivate and interest both male and female students and avoiding the topics that contrast with their nature and society, make them willing to use English inside the classroom. Students (males and females) might be willing to talk using English inside the classroom if their materials are drawn from instances related to actual life in the community because they are inextricably bound up with their society at large, having knowledge on what is going on outside. So, they can transfer their personal opinions to the classroom using English.

According to Wörde's study (2003), having a more 'personal relationship' with the students is helpful. Students are less anxious with the teacher who 'makes the class more animated', 'makes it interesting by using interesting situations'. The majority of the students assure that 'not being put on the spot' in class will help them to be less anxious.

Students should be encouraged to know each other outside the classroom in an attempt to create a friendly and intimate environment in which they never get afraid of each other's evaluation. Also, involving female and male students in mixed group-work to search for knowledge, references and sources of information in the libraries creates competitive atmosphere that reflect their broader abilities and teach them how gender influences access to powerful success.

Poynton (1989) points out that boys are proficient in attracting the teacher's attention and dominating turn-taking, so teachers should not give the male-students a chance to dominate the turns all the time and should not create a polarized focus on the male's speech because female-students will feel frustrated, more inhibited and suffer from "a lowering of self-esteem as they receive less attention" (Poynton: 1989, p 32).

\section{Acknowledgements}

My first word of gratitude must go to my husband, Dr.Ali Mohagab, whose suggestions, comments and advice helped me a lot to materialize this work. I shouldn't forget to thank my friend Dr.Ikhlas Al-jinaby and Mr.Mohammed Al-Syed for their help in analyzing the data of this study. 
International Journal of Applied Linguistics \& English Literature

ISSN 2200-3592 (Print), ISSN 2200-3452 (Online)

Vol. 1 No. 2; July 2012

\section{References}

Aida, Y. (1994). Examination of Horwitz, Horwitz, and Cope's construct of foreign language anxiety: The case of students of Japanese. The Modern Language Journal. 78(2), 155-168. Retrieved Oct. 2000 from http://dx.doi.org/10.2307/329005

Arnold, J. (Ed.) (1999). Affect in language learning. Cambridge : Cambridge University Press.

Baily, K. M.(1983). Competitiveness and anxiety in adult L2 learning : Looking at and through the Dairy studies.In H.W.Seliger \& M.H.Long. (Eds.) Classroom oriented research in second language acquistion.Rowley, MA: Newbury House, 67-103.

Bernat, E. (2002) Attending to adult learners: Affective domain in the ESL classroom.Retrieved 01 Oct. 2007, from http://www.hltmag.co.uk/sept04/mart2.htm

Campbell C. M., \& Ortiz, J. (1991). Helping students overcome foreign language anxiety: A foreign language anxiety workshop. In E. K. Horwitz and D. J. Young (Eds.). Language anxiety from theory to research to classroom implications. (pp. 153-168). Englewood Cliffs : Prentice Hall.

Chang, J. I. (1997). Contexts of adolescent worries: Impacts of ethnicity, gender, family structure, and socioeconomic status. Paper presented at the annual meeting of NCFR Fatherhood and Motherhood in a Diverse and Changing World, Arlington, VA.

Dakin, J. (1973). The language laboratory and language learning. London: Longman.

Daly, J. (1991). Understanding communication apprehension: An introduction for language educators. In Elaine K. Horwitz \& Dolly J. Young, Dolly J. (Eds.), Language anxiety: from theory and research to classroom implications (pp.3-13). Englewood Cliffs, NJ: Prentice Hall.

Ezzi. N. A. (2003). Gender sensitivity and its impact on communication within the classroom: The Yemeni experience. The English Classroom. 5 (1\&2),148-154. Regional Institute of English: India.

Ezzi. N. A (2006). The factors affecting English students' oral communicative competence in the Faculty of Education in Hodeidah. Unpublished PhD thesis, Mysore University: India.

Ezzi. N. A. (2012) Foreign Language anxiety and the young learners : Challenges ahead. Rethinking English Language Teaching: Proceedings of the $17^{\text {th }}$ TESOL Arabia Conference, 16, 56-62.

Gardner, R.C. \& MacIntyre, P.D. (1993). On the measurement of affective variables in second language learning. Language Learning, 43, 157-194.

Gierl, M. J., \& Rogers, W. T. (1996). A confirmatory factor analysis of the test anxiety inventory using Canadian high school students. Educational and Psychological Measurement, $56 \quad$ (2), 315-324. http://dx.doi.org/10.1177/0013164496056002012

Gregerson, T. (2003). To err is human: A reminder to teachers of language-anxious students. Foreign Language Annals, 36 (1), 25-32.

Horwitz, E.K., Horwitz, M. B. and Cope, J. (1986). Foreign language classroom anxiety. Modern Language Journal. 70 (2), 125-132.

Horwitz, E.K.(1991) Preliminary evidence for the reliability and validity of a foreign language anxiety scale. In E.K. Horwitz and D.J. Young.( Eds.) Language Anxiety: From theory and research to classroom implications (pp.109-126). Englewood Cliffs, NJ: Prentice-Hall.

Horwitz, E.K. and Young, D.J. (Eds.).(1991). Language anxiety: from theory and research to classroom implications. Englewood Cliffs, NJ: Prentice Hall.

Jafarigohar, M. \& Behrooznia, S. (2012). The Effect of anxiety on reading comprehension among distance EFL learners. International Education Studies, 5( 2), 159-174.

Liu, M. \& Jackson, J. (2008). "An exploration of Chinese EFL learners' unwillingness to communicate and foreign language anxiety". The Modern Language Journal, 92 (i), 71-86.

MacIntyre, P. D. (1999). Language anxiety: a review of the research for language teachers. In Young, D. (Ed.) Affect in foreign language and second language learning: a practical guide to creating a low-anxiety classroom atmosphere (pp. 24-45). Boston, MA: McGraw-Hill.

Mukalel, J.C. (1998). Creative Approaches to Classroom Teaching. Delhi: Discovery Publishing House.

Page $\mid 73$ 
International Journal of Applied Linguistics \& English Literature

ISSN 2200-3592 (Print), ISSN 2200-3452 (Online)

Vol. 1 No. 2; July 2012

Padilla, A. M., Cervantes, R. C., Maldonado, M., \& García, R. E. (1988). Coping responses to psychosocial stressors among Mexican and Central American immigrants. Journal of Community Psychology, 16 (4), $418-427$. http://dx.doi.org/10.1002/1520-6629(198810)16:4<418::AID-JCOP2290160407>3.0.CO;2-R

Piechurska-Kuciel, E. (2012). Language anxiety levels in urban, suburban and rural secondary grammar school students. In New perspectives on individual differences in language learning and teaching : Second language learning and teaching, Part 3, 169-183. DOI: 10.1007/978-3-642-20850-8_11

Plancherel, B. \& Bolognini, N. (1995). Coping and mental health in early adolescence. Journal of Adololescence,18 (4), 459-474. http://dx.doi.org/10.1006/jado.1995.1033.

Poynton, C. (1989). Language and gender: Making the difference. Oxford: Oxford University Press.

Puškar, K. (2010). A comparative study of foreign language anxiety among majors of English and German. PhD thesis. University of Zagreb.

Reid, J. (1999). Affect in the classroom: Problems, politics and pragmatics. In J. Arnold (Ed.) Affect in language learning. Cambridge : Cambridge University Press, 297-306.

Siegel, L. S. (1989). IQ is irrelevant to the definition of learning disabilities. Journal of Learning Disabilities, $22,469-478$

Spielberger, C.D. (1983). Manual for the state-trait anxiety inventory (form Y). Palo Alto, California: Consulting Psychologists Press.

Tanveer, M.( 2007) . Investigation of the factors that cause language anxiety for ESL/EFL learners in learning speaking skills and the influence it casts on communication in the target language. $\mathrm{PhD}$ thesis. University of Glasgow.

Von Wörde, R. A. (2003). Students' perspectives on foreign language anxiety. Inquiry, 8(1). Retrieved May 2008 from http://www.vccaedu.org/inquiry/inquiry-spring2003/i-81-worde.html.

Wei, J. \& Yodkamlue, B. (2012). The Chinese Bouyei college students' classroom anxiety in foreign language learning: A survey study. International Journal of English Linguistics, 2 ( 2); 75- 90. 
International Journal of Applied Linguistics \& English Literature

ISSN 2200-3592 (Print), ISSN 2200-3452 (Online)

Vol. 1 No. 2; July 2012

\section{Appendix}

استبنيـان

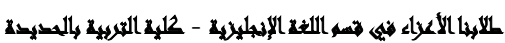
لطفا منكم الأجابه على هذا الاستبيان لغرض علمي بحت وذللك بوضع علامة ( ل ) في المريع المناسب:

$\square$ أنثى

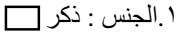
$\square$ بين
$\square$ بين

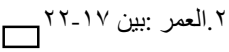

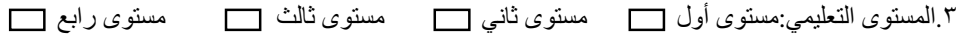

\begin{tabular}{|c|c|c|c|c|c|c|}
\hline معارض & 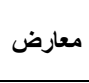 & 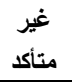 & 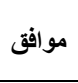 & 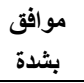 & 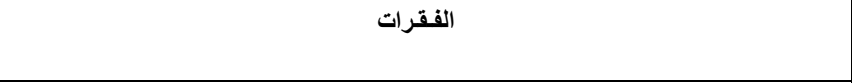 & 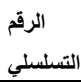 \\
\hline & & & & & أشعر بعدم الثقة في نفسي عندما أتحدث باللغة الأنجليزيه في المحاضرة. & 1 \\
\hline & & & & & لا أهتم بارتكاب الأخطاء اللغوية في المحاضرة & r \\
\hline & & & & & أرتبك عندما يحين دوري للتحدث باللغة الأنجليزيه في المحاضرة. & $r$ \\
\hline & & & & & عدم فهمي لما يقوله المدرس في المحاضرة يخيفني كثيرا & $\varepsilon$ \\
\hline & & & & & لا يضايقني أخذ محاضرات إضافية في اللغة الإنجليزية. & 0 \\
\hline & & & & & أثثاء محاضرة اللغة الإنجليزية أجد نفسي أفكر في أثياء بعيده كل البعد عن محتوى المحاضرة. & 7 \\
\hline & & & & & أثنعر دائما أن مستوى بقية الطلاب في اللغة الأجليزيه أفضل مني. & $\mathrm{v}$ \\
\hline & & & & & تكون أعصابي هائة تماما أثناء فترة امتحانات اللغة الأنجليزيه. & $\wedge$ \\
\hline & & & & & ينتابني الثعور بالذعر مباشرةً عندما أضطر للتحدث باللغة الأنجليزيه بدون إعداد مسبق. & 9 \\
\hline & & & & & أثنعر بخوف شديد لاحتمال رسوبي في اللغة الانجليزية. & 1. \\
\hline & & & & & لا أفهم لماذا بعض الزملاء يستاعوا من محاضرات اللغة الإنجليزية. & 11 \\
\hline & & & & & أستاء عندما أنسى أثياء كنت أعرفها في اللغة الأنجليزيه. & ir \\
\hline & & & & & أتردد كثير ا في أن أتطوع لأجابه على الأسئلة في محاضرة اللغة الأنجليزيه. & ir \\
\hline & & & & & أثعر بالراحة للتحدث باللغة الأنجليزيه مع المتحدثين الأصلين لها. & $1 \leq$ \\
\hline & & & & & أستاء عندما لا أفهم ما الذي قام العدرس بتصحيحه من أخطاء. & 10 \\
\hline & & & & & أخثى من حضور محاضرات اللغة الإنجليزية حتى وإن قمت بالتحضير المسبق لهه. & 14 \\
\hline & & & & & غالبا أشعر أني لا أرغب في حضور محاضرات اللغة الإنجليزية. & iv \\
\hline & & & & & أثشعر بالثقة في نفسي عندما أتحدث باللغة الإنجليزية في المحاضرة. & 11 \\
\hline & & & & & أخاف عندما يقوم المدّرس بتصحيح كافة الأخطاء التي أقع فيها بالمحاضرة. & 19 \\
\hline & & & & & قلبي يرتجف بثده عندما يأتي دوري للتحدث باللغة الإنجليزية. & r. \\
\hline & & & & & الاستعداد الكثير للامتحان يجعلني أتثوش كثيرا & ri \\
\hline & & & & & لا أثعر بقلق عندما أحضر جيدا للمحاضرة. & rr \\
\hline & & & & & أشعر دائما أن بقية الطلاب يتحدثون اللغة الإنجليزية أفضل مني. & re \\
\hline & & & & & أشعر بارتباك شديد عندما أتحدث باللغة الإنجليزية أمام بقية الطلاب. & $r \leq$ \\
\hline & & & & & أشعر بالقلق من عدم استيعاب المحاضرات التي تمر سريعا. & ro \\
\hline & & & & & أثتعر بأني متوتر وعصبي في محاضر ات اللغة الإنجليزية أكثر من غيرها من المحاضرات. & rq \\
\hline & & & & & أشعر بالارتباك و التشويش عندما أتحدث في محاضرة اللغة الإنجليزية. & rv \\
\hline & & & & & أشعر بالثقة والارتياح عند يأتي موعد محاضرة اللغة الانجليزية. & rA \\
\hline & & & & & أشعر بالتوتر عندما لا أفهم كل كلمه يقولها المدرس في المحاضرة. & rq \\
\hline & & & & & يزعجني كثرة القواعد اللغوية التي يجب أن أتعلمها لأستطيع التحدث باللغة الإنجليزية. & $r \cdot$ \\
\hline & & & & & أخثى من سخرية زملاني مني عندما أتحدث باللغة الإنجليزية. & 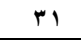 \\
\hline & & & & & أشعر بارتياح في حال وجود المتحدثين الأصلين للغة الإنجليزية. & re \\
\hline & & & & & أثنعر بالقلق عندما يسأل المدرس اسئله لم أستعد لها مسبقاً. & $r r$ \\
\hline & & & & & 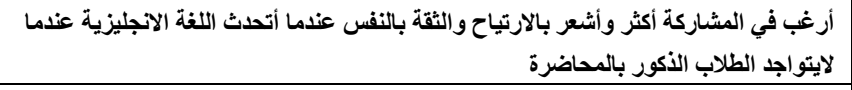 & $r \leq$ \\
\hline & & & & & 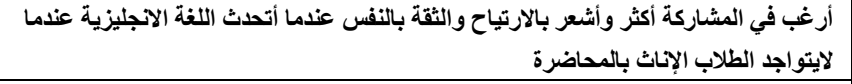 & ro \\
\hline & & & & & أشعر بالارتياح وأرغب في المشاركة أكثر إذا كان المدّرس رجل وليس إمراة بالمحاضرة. & m \\
\hline & & & & & أشعر بالارتياح وأرغب في المشاركة أكثر إذا كان المدُرس إمراة وليس رجل بالمحاضرة. & rv \\
\hline
\end{tabular}

Page $\mid 75$ 